УДК 378.147.016:62

DOI:

Леонід Оршанський, доктор педагогічних наук, професор, завідувач кафедри технологічної та професійної освіти Дрогобицького державного педагогічного університету імені Івана Франка Ліліана Маркова, заступник директора Стрийського коледжу Львівського національного аграрного університету

\title{
РЕАЛІЗАЦІЯ КОМПЕТЕНТНІСНОГО ПІДХОДУ У ПРОЦЕСІ ПДГОТОВКИ МАЙБУТНІХ ФАХІВЦІВ ІНЖЕНЕРНО-ТЕХНІЧНОГО ПРОФІЛЮ
}

У статті визначена місія закладів передвищої та вищої інженерно-технічної освіти в умовах реформування освітньої галузі, обгрунтовані концептуальні засади реалізації компетентнісного підходу та формування професійної компетентності майбутнього фахівия інженерно-технічного профілю. На основі аналізу наукових праць та вивчення реальної освітньої практики визначені напрями вдосконалення системи підготовки фахівиів інженерно-технічного профілю з позиції реалізаиії компетентнісного підходу та розроблена відповідна педагогічна модель, щзо враховує суспільні вимоги і прогностичність розвитку науки, техніки та виробництва.

Визначені чинники підвищення ефективності інженерно-технічної освіти та технологій реалізації компетентнісного підходу як складової педагогічної системи із заданими властивостями, а також запропонований комплекс інновачійних освітніх технологій формування професійноӥ компетентності як показника якості інженерно-технічної освіти.

Ключові слова: інженерно-технічна освіта; компетентнісний підхід; педагогічні мови; формування професійних компетентностей; заклади освіти; майбутні фахівиі інженерно-технічного профілю.

Jim. 7.

Leonid Orshanskiy, Doctor of Sciences (Pedagogy), Professor, Head of the Technological and Professional Education Department Drohobych Ivan Franko State Pedagogical University Liliana Markova, Deputy Director of Striy College, Lviv National Agrarian University

\section{REALIZATION OF COMPETENCE APPROACH IN THE PROCESS OF TRAINING OF FUTURE SPECIALISTS OF ENGINEERING AND TECHNICAL PROFILE}

The article defines the mission of pre-higher and higher engineering educational institutions in terms of reforming the education sector; substantiates the conceptual foundations for the implementation of the competency approach and the formation of professional competence of the future specialists in engineering. It identifies the areas for improving the training of engineers and technical specialists from the standpoint of implementing a competency-based approach based on the analysis of scientific publications and the study of hands-on educational experience. It also designs an appropriate pedagogical model that takes into account social requirements and anticipated development of science, technology and production.

The article also defines the factors that increase effectiveness of engineering-technical education and technologies of realization of the competency-based approach as a component of the pedagogical system with the set properties. It also conceives the complex of innovative educational technologies of formation of the following professional competences as an indicator of quality of engineering-technical education: information-pedagogical (dialogue-oriented learning methods, on-line seminars-discussions, problem-based learning in webinars, introduction of electronic portfolios); project-activity (project method, contextual learning, organizational-activity games, complex tasks, technological maps, simulation-game modeling, etc.); personality-oriented (interactive and simulation games, trainings, developmental psycho-diagnostics, etc.).

Keywords: an engineering education; competence approach; pedagogical languages; formation of professional competencies; educational institutions; future specialists in engineering.

$\Pi$ остановка проблеми. В умовах зростання конкуренції, становлення ринкових відносин, появи нових професій підготовка інженерно-технічних працівників, здатних розвивати високотехнологічні галузі виробництва, забезпечувати конкурентоспроможність і обороноздатність країни, набуває актуального значення. Підтвердженням цього $є$ спрямованість вітчизняної фахової передвищої та вищої освіти на послідовну інтеграцію в європейський освітній простір, що вимагає якісно нових підходів до підготовки інженерних кадрів. При цьому трансформація інженерно-технічної освіти 
зумовлюється місією закладу освіти, де пріоритетними вважаються завдання гнучкого управління інтелектуальними і матеріальними ресурсами, стимулювання інноваційної діяльності, позиціонування на ринку освітніх послуг, що в сукупності забезпечують виникнення якісно нової системи, спрямованої на підготовку в технічних вишах висококваліфікованих фахівців.

У цих умовах передвища та вища інженернотехнічні школи покликані формувати професійну компетентність майбутніх техніків, технологів та інженерів, забезпечувати готовність випускників до створення і експлуатації технічних об'єктів, що відповідають вимогам ефективності й економічності. Успіх реалізації цього завдання передовсім визначається активізацією розвитку стратегії компетентнісного підходу, що передбачає організацію освітнього процесу, націленого на забезпечення якості підготовки випускника, оволодіння професійними компетенціями, інтелектуальними, комунікативними, моральноетичними якостями, що сприяють успішному здійсненню професійної діяльності в широкому соціальному, економічному та культурному контекстах [4].

Сьогодні, коли здійснено перехід на багаторівневу підготовку фахівців, впроваджуються сучасні моделі менеджменту передвищої та вищої освіти, проходить становлення система акредитації європейського типу (НАЗЯВО), реалізуються нові освітні парадигми (інформаційно-педагогічна, особистісно орієнтована тощо), актуального значення набуває підготовка майбутніх фахівців 3 інженерно-технічного профілю на основі компетентнісного підходу, що, з одного боку, забезпечує реалізацію вимог Болонського процесу, впровадження стандартів третього покоління, а 3 іншого - передбачає кардинальну зміну системи інженерно-технічної освіти, оновлення іï структури, впровадження інноваційних технологій навчання тощо.

Проведений з цих позицій аналіз літератури вказує на відображення у наукових працях різних аспектів реалізації компетентнісного підходу у фаховій передвищій та вищій освіті, де: досліджені різні види і типи компетентностей (Н. Бібік, Л. Ващенко, І. Срмаков, О. Локшина, О. Овчарук, Л. Паращенко, О. Пометун й ін.); обгрунтовані умови і дидактичні засади формування компетентності техніка, технолога, інженера (I. Белоновська, Н. Боярчук, М. Головань, В. Жигірь, І. Каньковський, О. Коваленко, А. Нізовцев, І. Огороднійчук, А. Семенова, Л. Тархан та ін.); описана практика реалізації компетентнісного підходу в інформаційно- освітньому середовищі (В. Биков, А. Вознюк, О. Глазунова, Р. Гуревич, О. Джеджула, М. Жалдак, М. Кадемія, Л. Макаренко, М. Стефаненко та ін.). Актуальне значення мають наукові праці зарубіжних учених з теорії компетентнісного підходу (Р. Бадер, Д. Мертенс, Б. Оскарсон, А. Шелтен); розвитку компетентностей (М. Бернс, Дж. Сандберг, О. Нордхог, Т. Шаморро-Премузіч, А. Фернем); розроблення інноваційних моделей управління знаннями (Дж. Буске, Дж.Ф. Шрейнмакер); організації комунікацій (В. Шрамм, Н. Луманн, Ч. Кулі) та ін., де з різних позицій розглядаються проблеми інженерно-технічної підготовки фахівців. При тому слід визнати факт недостатньої кількості та якості спеціальних досліджень, присвячених реалізації компетентнісного підходу в інженернотехнічній освіті.

Мета статті: визначити педагогічні умови реалізації компетентнісного підходу у процесі інженерно-технічної підготовки майбутніх фахівців 3 інженерно-технічного профілю.

Виклад основного матеріалу. Аналіз наукових праць (М. Гуржій, М. Дмитриченко, I. Драч, В. Зайчук, М. Згуровський, Ю. Зіньковський, С. Калашнікова, С. Курбатов, В. Мадзігон, Н. Ничкало, С. Ніколаєнко, В. Радкевич, О. Слюсаренко, Ж. Таланова та ін.), в яких розглядаються фундаментальні проблеми передвищої та вищої школи, дозволяє зробити висновок про зміну основних поглядів на цілі професійної та, зокрема, інженерно-технічної освіти. Одночасно в теорії і практиці освіти актуалізуються положення та принципи педагогіки, які зумовлюють парадигмальний підхід до дослідження проблем професійної освіти, де особливе місце займає розроблення критеріїв освіченості фахівця інженерно-технічного профілю, його компетентності, що детермінуються професійними знаннями i варіативними соціально значущими характеристиками.

Слід зазначити, що в науковій полеміці про методологію і напрям розвитку інженернотехнічної освіти (С. Балджи, I. Драч, С. Калашнікова, О. Коваленко та ін.) питання парадигми розглядається в різних площинах [1]. При цьому парадигмальний контекст пов'язаний iз запозиченням кращої міжнародної практики інженерно-технічної освіти, яка реалізується через інститут незалежної акредитації освітніх програм й ефективну систему управління якістю освіти. Крім того, зроблений нами аналіз наукової літератури виявив такі основні напрями зарубіжних досліджень: 1) зміна парадигми інженерно-технічної освіти (Дж. Бордонья, Е. Фромм, Е.В. Ернст); 2) зміна глобальної мети, яка полягає у становленні цивілізаційного діалогу 


\section{РЕАЛІЗАЦІЯ КОМПЕТЕНТНІСНОГОПІДХОДУ У ПРОЦЕСІПДГОТОВКИ МАЙБУТНІХ ФАХІВЦІВ ІНЖЕНЕРНО-ТЕХНІЧНОГОПРОФІЛЮ}

щодо інженерно-технічної освіти (М. Вагнер, М. Каланціс); 3) необхідність внесення професійного, гуманітарного, національного розмаїття в інженерно-технічну освіту, зумовленого епохальними викликами і варіативними очікуваннями студентів (К. Мейерс, Е. В. Ернст); 4) трансформація технічної освіти в річищі зміни традиційної практики, що грунтується на всеохоплюючому прагматизмі управління природою, а не співпраці з нею (Б. Амадей) та ін. [7].

У дослідженнях сучасних вітчизняних педагогів [3-5] ефективність інженерно-технічної освіти пов' язується з чинниками, структурованими нами в такі проблемні поля:

1) системні - пов'язані із забезпеченням відповідності сучасної системи професійної підготовки інженерно-технічних кадрів вимогам, відображеним в професійних стандартах передвищої та вищої освіти; зі зменшенням розриву між інформаційно-технологічною революцією й обмеженими можливостями щодо сприйняття і1і досягнень вищою інженернотехнічною школою; з орієнтацією навчання на формування фрагментарних предметнотехнологічних знань, умінь і навичок, необхідністю ïх системного використання у процесі практичної діяльності; з підготовкою фахівців для роботи у нестандартних умовах, що не забезпечує система навчання зі застарілими методами інформаційного характеру, переважанням теоретичної складової підготовки і незначним акцентом на практичне використання знань у професійній діяльності;

2) процесуальні - пов'язані з невідповідністю реального стану професійної підготовки фахівців та сучасних вимог суспільства до інженернотехнічної освіти; зі зростанням інтеграційних процесів в системі “освіта, наука і виробництво” при недостатньому рівні методологічного апарату їх використання; з наявністю об'єктивної потреби в удосконаленні компетенцій фахівця у різних аспектах професійної діяльності; $з$ нерозробленістю дидактичної системи інноваційної професійної підготовки компетентних фахівців; з отриманням знань “в статиці” при актуальності їх розгортання у технологічних процесах майбутньої професійної діяльності; з відсутністю “оперативності” знань, які виступають психологічним бар'єром при прийнятті рішень у виробничих ситуаціях;

3) технологічні, пов'язані 3 необхідністю використання в професійній підготовці інформаційно-комунікаційних технологій; 3 теоретичним обгрунтуванням змістовної частини електронних освітніх ресурсів і їх можливостей; 3 адаптацією педагогічних технологій до розв'язання проблеми визначення мети в інженерно-технічному закладі передвищої або вищої освіти;

4) якісні, пов'язані з необхідністю розроблення концепції забезпечення якості підготовки фахівців 3 вищою інженерно-технічною освітою в умовах дії конкуренції; з перспективністю компетентнісного підходу до проблеми оцінки якості інженернотехнічної освіти та розвитком іїі методологічного забезпечення;

5) змістовно-організаційні, пов'язані 3 потенційними можливостями загальнотехнічних і спеціальних дисциплін та розширенням їх реального внеску в підвищення професійної готовності сучасного фахівця; 3 цілями, змістом, формами організації, умовами навчальної та майбутньої професійної діяльності; з системністю, міждисциплінарністю, наддисциплінарністю, вмотивованістю використання загальних і професійних компетенцій фахівця та їх формуванням у межах окремих навчальних дисциплін;

6) кваліметричний, пов'язаний з необхідністю якісної оцінки підготовки фахівців інженернотехнічного профілю за допомогою вироблення універсальних критеріїв її визначення.

Порівняльний аналіз публікацій показує, що в педагогічній науці сучасними вченими досліджені різні види компетентності, зокрема: професійнокомунікативна, міжкультурна, професійна, екологічна, проєктно-конструкторська, квалітативна, управлінська, аналітична, інформаційнотехнологічна та ін. Слід зазначити, що перераховані вище компетентності розглядаються як локальні результати професійної підготовки, натомість сучасна парадигма інженерно-технічної освіти, що грунтується на компетентнісній основі, передбачає формування узагальненої професійної компетентності майбутніх фахівців. Із цих позицій компетентнісний підхід в інженерно-технічній освіті слід розглядати як опис результатів навчання на мові компетенцій, що передбачає організацію освітнього процесу, спрямованого на забезпечення готовності фахівців до здійснення продуктивної професійної діяльності. Крім того, система формування професійної компетентності майбутніх фахівців інженерно-технічного профілю повинна мати явно виражений міждисциплінарний, інтегративний, практико-орієнтований характер, що уможливить підготувати випускників до продуктивної діяльності, забезпечити їх відповідність до стрімко зростаючих вимог соціально-економічного, професійного характеру.

Більшість моделей впровадження компетентнісного підходузосереджені наструктурі компетентності як 


\section{РЕАЛІЗАЦІЯ КОМПЕТЕНТНІСНОГОПДХОДУ У ПРОЦЕСІПІДГОТОВКИ}

\section{МАЙБУТНІХ ФАХІВЦІВ ІНЖЕНЕРНО-ТЕХНІЧНОГО ПРОФІЛЮ}

прогностичної мети педагогічного процесу, натомість в інженерно-технічних спеціальностях важливим є розуміння динаміки розвитку самої професійної компетентності, тобто прогнозування запитів з боку ринку праці, які покликана задовольнити система передвищої та вищої освіти.

Аналіз освітньої практики показує, що динаміка науково-технічного прогресу здебільшого випереджає знання, які збувають студенти у процесі професійної підготовки, внаслідок чого актуалізується необхідність проєктування освітньої моделі, що грунтується на принципах випереджувального навчання та $є$ важливою умовою забезпечення якості інженернотехнічної освіти. Слід зазначити, що з цих позицій компетентність випускника $є$ контекстуальною та проявляється у результатах професійної діяльності, звуження якої до результату професійної підготовки суперечить реалізації ідеї компетентнісного підходу в інженерно-технічній освіті. Це підтверджується також результатами міжнародного досвіду, коли у випускників зарубіжних закладів професійної освіти передовсім формується здатність працювати в міждисциплінарних проєктах, розвиваються здібності до самоосвіти, стимулюються бажання навчатися упродовж життя. Крім того, в європейських системах багаторівневої інженернотехнічної освіти активне впровадження освітніх програм на рівнях “молодший бакалавр бакалавр - магістр” відбувається через узгодження змісту навчання зі стейкголдерами, представниками промисловості, які виступають зацікавленими сторонами та роботодавцями.

Розглядаючи питання якості підготовки фахівців, необхідно відзначити важливість інноваційної інженерно-технічної освіти як центральної проблем щодо затребуваності випускників вишів у системі національної економіки, міжнародного визнання вітчизняних ступенів і кваліфікацій, що безпосередньо залежить від змісту і технологій реалізації освітніх програм. При цьому основними умовами переходу до інноваційного інженерно-технічної освіти нами розглядаються:

1) оновлення змісту професійної підготовки 3 погляду впровадження інноваційних технологій;

2) виявлення та використання кращих вітчизняних і зарубіжних аналогів освітніх програм;

3) інтеграція підприємницьких ідей у зміст професійно-орієнтованих навчальних дисциплін;

4) упровадження інтегрованих освітніх програм (на кшталт програм подвійних дипломів);
5) використання методів професійної підготовки, які забезпечують продуктивну діяльність.

Інноваційність інженерно-технічної освіти повинна забезпечуватися не лише актуалізацією теоретичного матеріалу, демонстрацією зв'язків пропонованого навчального матеріалу 3 майбутньою професійною діяльністю, а й урахуванням перспектив технічного, технологічного, економічного і соціального розвитку суспільства, що дає змогу майбутньому фахівцеві виробити необхідний рівень мотивації до навчання, готовність до освоєння теорії через практику.

Аналіз сучасної інженерно-технічної освіти 3 позицій реалізації компетентнісного підходу засвідчив, що суспільство вимагає від закладів передвищої та вищої освіти здійснення професійної підготовки інженерно-технічних кадрів, здатних створювати інноваційний продукт, що відповідає вимогам стандартів третього покоління. При цьому необхідно створити таку інноваційну систему, що уможливить формування у майбутніх фахівців готовність до професійної діяльності на якісно новому рівні.

Інноваційна система інженерно-технічної освіти через свої компоненти розкриває теорію і методику формування проєктувальних, конструктивних, гностичних, комунікативних, управлінських й інших умінь, а також технікотехнологічних знань і навичок оволодіння специфічними способами професійної діяльності. При цьому забезпечується інтеграція міжнаукових і міждисциплінарних зв'язків, використання системних методів, включення до актуальних наукових досліджень. Системоутворювальним компонентом виступає мета інноваційної педагогічної системи, оскільки саме щодо неї зазвичай впорядковані інші елементи системи, яка в контексті забезпечення професійної компетентності майбутнього фахівця інженернотехнічного профілю є основним зовнішнім чинником, що сприяє виникненню і розвитку цієі системи. Компонентами інноваційної педагогічної системи інженерно-технічної освіти виступають: принципи, зміст, форми організації, методи та засоби навчання, організаційно-педагогічні умови, а також інноваційні освітні технології, які забезпечують певний рівень системності.

Щодо інноваційних освітніх технологій, то вони $\epsilon$ комплексом прогресивних форм організації освітнього процесу, методів і сучасних засобів навчання, інформаційно-освітніх ресурсів, спрямованих на формування інноваційноорієнтованого освітнього середовища підготовки фахівців, які володіють комплексом професійних 


\section{РЕАЛІЗАЦІЯ КОМПЕТЕНТНІСНОГОПДХОДУ У ПРОЦЕСІПДГОТОВКИ МАЙБУТНІХ ФАХІВЦІВ ІНЖЕНЕРНО-ТЕХНІЧНОГОПРОФІЛЮ}

та соціальних компетенцій, а також інноваційним мисленням. При цьому для реалізації системи формування компетентності майбутнього фахівця інженерно-технічного профілю пріоритетними є:

1) інформаційно-педагогічні технології, де використовуються проблемно-діалогічні методи навчання, семінари-дискусії у режимі on-line, проблемне навчання в умовах вебінарів, впровадження електронних портфоліо;

2) проєктно-діяльніснітехнології,девикористовуються методпроєктів, контекстне навчання, організаційнодіяльні ігри, комплексні завдання, технологічні карти, імітаційно-ігрове моделювання та ін.;

3) особистісноорієнтовані технології 3 використанням інтерактивних й імітаційних ігор, тренінгів, розвивальної психодіагностики тощо.

Висновки та перспективи подальших досліджень. Отже, на сучасному етапі розвитку вітчизняної інженерно-технічної освіти особливої актуальності набуває питання зміни динаміки та структури педагогічного процесу, головною метою якого $є$ формування фахівця, здатного розв'язувати широкий спектр завдань 3 високим ступенем інноваційної домінанти в професійній діяльності. 3'ясовано, що компетентнісноорієнтована освіта встановлює реалізовану в педагогічній практиці компетентнісну модель інженерно-технічної освіти, де основним результатом є спеціальні професійні та ключові компетенції випускника, сформовані відповідно до вимог професійних стандартів і запитів роботодавців

Подальший науковий пошук слід спрямувати на визначення дієвих педагогічних умов формування професійної компетентності фахівців інженерно-технічного профілю в умовах реформування системи передвищої та вищої освіти.

\section{ЛІТЕРАТУРА}

1. Балджи С., Драч І., Калашнікова С., Коваленко О. та ін. Розвиток інституційного потенціалу університетів у контексті глобального лідерства: монографія / за заг. ред. С. Калашнікової. Київ: Інститут вищої освіти НАПН України, 2017. $205 \mathrm{c}$.

2. Карпаш М., Крижанівський Є., Карпаш О. Вища інженерна освіта в умовах сталого розвитку суспільства. Вища освіта Украӥни. 2014. № 2. С. 55-60.

3. Корсак К., Тарутіна 3., Похресник А., Козлакова Г., Гуржій А. та ін. Теоретико-методологічні основи модернізації природничої й інженерної вищої освіти в умовах інноваційно-технологічного розвитку суспільства: монографія. Київ, 2014. 202 с

4. Огороднічук I. А. Особливості формування компетентності майбутніх інженерів. Наука і освіта. 2013. №1-2. С. 193-197.

5. Пожуєв В. І. Ключові проблеми сучасної інженерної освіти в контексті реформи вищої освіти.
Гуманітарний вісник Запорізької державної інженерної академії. 2006. Вип. 24. С. 4-14.

6. Психолого-педагогічні засади проектування інноваційних технологій викладання у вищій школі: монографія / за заг. ред. В.П. Андрущенка, В.І. Лугового. Київ: Пед. думка, 2011. 260 с.

7. Стратегії вищої освіти в умовах інтернаціоналізації для стійкого розвитку суспільства: методичні рекомендації / В. Зінченко, Л. Горбунова, С. Курбатов, Ю. Мєлков; за ред. В. Зінченка. Київ: Інститут вищої освіти НАПН України, 2019. 107 с.

\section{REFERENCES}

1. Baldzhy, Ye., Drach, I., Kalashnikova, S. \& Kovalenko, O. et al. (2017). Rozvytok instytutsiinoho potentsialu universytetiv u konteksti hlobalnoho liderstva: monohrafiia [Development of institutional potential of universities in the context of global leadership: a monograph]. (Ed.). S. Kalashnikova. Kyiv, 205 p. [in Ukrainian].

2. Karpash, M., Kryzhanivskyi, Ye. \& Karpash, O. (2014). Vyshcha inzhenerna osvita $\mathrm{v}$ umovakh staloho rozvytku suspilstva [Higher engineering education in the conditions of sustainable development of society]. Higher education in Ukraine.No. 2. pp. 55-60. [in Ukrainian].

3. Korsak, K., Tarutina, Z., Pokhresnyk, A., Kozlakov, H. \& Hurzhii, A. et al. (2014).Teoretyko-metodolohichni osnovy modernizatsii pryrodnychoi y inzhenernoi vyshchoi osvity $\mathrm{v}$ umovakh innovatsiinotekhnolohichnoho rozvytku suspilstva: monohrafiia [The theoretical and methodological bases of modernization of natural and engineering higher education in the conditions of innovative and technological development of society: monograph]. Kyiv, 202 p. [in Ukrainian].

4. Ohorodnichuk, I. A. (2013). Osoblyvosti formuvannia kompetentnosti maibutnikh inzheneriv [The features of formation of competence of future engineers]. Science and education. No.1-2.pp. 193-197. [in Ukrainian].

5. Pozhuiev, V. I. (2006). Kliuchovi problemy suchasnoi inzhenernoi osvity $\mathrm{v}$ konteksti reformy vyshchoi osvity [The key problems of modern engineering education in the context of higher education reform]. Humanitarian Bulletin of the Zaporizhzhya State Engineering Academy.Vol. 24.pp. 4-14.[in Ukrainian].

6. Psykholoho-pedahohichni zasady proektuvannia innovatsiinykh tekhnolohii vykladannia u vyshchii shkoli: monohrafiia (2011). [The psychological and pedagogical principles of designing of innovative teaching technologies in higher school: monograph]. (Ed.). Andrushchenko V.P., Luhovyi V.I. Kyiv, 260 p.[in Ukrainian].

7. Zinchenko, V., Horbunova, L., Kurbatov, S. \& Mielkov, Yu. (2019). Stratehii vyshchoi osvity v umovakh internatsionalizatsii dlia stiikoho rozvytku suspilstva: metodychni rekomendatsii [The strategies of higher education in the conditions of internationalization for sustainable development of society: methodical recommendations]. (Ed.).V. Zinchenko. Kyiv, 107 p. [in Ukrainian].

Стаття надійшла до редакції 01.07.2020 